\title{
Toxicity of Bacillus thuringiensis CrylAb Toxin to the Predator Chrysoperla carnea (Neuroptera: Chrysopidae)
}

\author{
ANGELIKA HILBECK, WILLIAM J. MOAR, ${ }^{1}$ MARIANNE PUSZTAI-CAREY, ${ }^{2}$ AGATA FILIPPLNI, \\ AND FRANZ BIGLER
}

Swiss Federal Research Station for Agroecology and Agriculture, CH-8046 Zürich, Switzerland

\begin{abstract}
Environ. Entomol. 27(5): 1255-1263 (1998)
ABSTRACT Laboratory feeding studies were carried out to determine the effects of the Bacillus thuringiensis (Berliner) Cryl Ab toxin on developmental time and mortality of Chrysoperla camea (Stephens) larvae. A bioassay technique was developed that allowed for incorporation of the CrylAb toxin into a liquid diet that was then encapsulated within small paraffin spheres. Because only 2 nd and 3rd instars can penetrate the surface of the paraffin spheres, 2 different methods were used to rear chrysopid larvae through the 1st instar. The lst method used small foam cubes soaked in non-encapsulated, liquid diet (with or without Cryl Ab). The 2nd method used Ephestia kuehniella (Hübner) eggs as prey during the first instar (no CrylAb exposure). After reaching the 2nd instar, all larvae received encapsulated, artificial diet with or without CrylAb, respectively. When reared only on artificial diet containing CrylAb toxin, total immature mortality was significantly higher $(57 \%)$ than in the respective untreated control $(30 \%)$. Also, significantly more chrysopid larvae died (29\%) that received CrylAb later during their larval development compared with the respective control (17\%). Although mortality was consistently higher, no or only small differences in developmental times were observed between CrylAb-treated and untreated C. carnea larvae. C. carnea larvae required significantly more time to complete larval development when reared on artificial diet only than when reared first on E. kuehniella eggs followed by encapsulated artifical diet or on only E. kuehniella eggs, regardless of exposure to CrylAb. These results demonstrate that $\mathrm{Cry} 1 \mathrm{Ab}$ is toxic to C. carnea at $100 \mu \mathrm{mg} / \mathrm{ml}$ of diet by using encapsulated artificial diet.
\end{abstract}

KEY WOHDS Chrysoperla carnea, Bacillus thuringiensis, CrylAb, risk assessment, natural enemies, biological control

THE USE OF Bacillus thuringiensis (Berliner) to control insect pests is expected to increase dramatically in agroecosystems of many countries in the coming years, primarily through transgenic plants expressing B. thuringiensis proteins. In 1997, nearly 3.65 million ha of $B$. thuringiensis crops were planted in the United States, $\approx 2.84$ million ha of Bt corn, 0.7 million ha of Bt cotton and 10,000 ha of Bt potato (Mellon and Rissler 1998). Products containing $B$. thuringiensis have been used in agriculture for several decades and are commonly considered to have little or no effect on natural enemies of pest insects (Croft 1990, Flexner et al. 1986, Melin and Cozzi 1989). This opinion is primarily based upon previous studies that were designed to test for undesired side effects of $B$. thuringiensis compounds on beneficial insects when used as a foliar insecticide (Croft 1990). However, B. thuringiensis insecticides and transgenic plants expressing $B$. thuringiensis differ in a number of aspects. In most commercially available transgenic plants expressing $B$. thuringiensis, the $B$. thuringiensis proteins are produced in relatively high

\footnotetext{
${ }^{1}$ Department of Entomology, Auburn University, Auburn, AL 36849-5413.

2 Department of Biochemistry, Case Western Reserve University, Cleveland, $\mathrm{OH} 44106-4936$.
}

levels in a large proportion of the plants throughout most of their growing period until the plants senesce (Koziel et al. 1993, Perlak et al. 1990). Therefore, most if not all herbivores colonizing transgenic plants expressing $B$. thuringiensis during the season also will feed on and ingest plant tissue containing $B$. thuringiensis protein that they may pass on to their natural enemies in a more or less processed form. Furthermore, most $B$. thuringiensis proteins in transgenic plants are expressed in a truncated, activated form (Perlak et al. 1990, Fujimoto et al. 1993, Koziel et al. 1993) that differs from $B$. thuringiensis proteins found in B. thuringiensis crystals present in microbial B. thuringiensis insecticides (Feitelson et al. 1992). Hence, selectivity of $B$. thuringiensis proteins expressed in transgenic plants cannot simply be deduced from the long record of safety for the use of commercial $B$. thuringiensis insecticides. Recently, it has been suggested that current assessment methods do not adequately account for the modified, activated form of $B$. thuringiensis proteins expressed in transgenic plants and the extended duration of availability to herbivores and, consequently, to other members of the food chain beginning with the natural enemies of these herbivores (Goldburg and Tjaden 1990, Jepson et al. 1994, 
Snow and Palma 1997). This study was intended as an initial step in this direction.

The predaceous larvae of Chrysoperla carnea (Stephens) are important natural enemies in many agricultural systems throughout the world (New 1975). Its immature life stage consists of 3 instars that all are voracious predators of many pest species, including aphids and lepidopterous pests, and a nonfeeding pupal stage. Because of its importance in biological control, C. carnea is one of the most commonly tested species for pesticide side-effects (Croft 1990). Hilbeck et al. 1998 demonstrated that $C$. carnea larvae raised on 2 different prey species that had fed on transgenic, CrylAb-expressing corn leaves, Zea mays (L.), had significantly higher mortality compared with C. carnea larvae fed prey species that had fed on nontransformed, Cryl Ab-free corn leaves. However, Croft (1990) noted that lethal and sublethal impacts of $B$. thuringiensis on natural enemies may not be directly related to the proteins but may result from the effect of the B. thuringiensis compounds on the nutritional quality of the pest insect. Additionally, potential modifications of a plant's chemistry cannot be ruled out when expressing a foreign gene. Therefore, to be able to differentiate direct effects of $B$. thuringiensis proteins from indirect effects on $C$. carnea, laboratory bioassays that use purified CrylAb protein (similar to the protein expressed in corn) and artificial diet are necessary.

A major obstacle in conducting feeding bioassays with C. carnea has been that the larvae typically suck their food from within a substrate. In previous studies investigating direct effects of $B$. thuringiensis proteins on $C$. carnea, the surface of Sitotroga cerealella (Olivier) eggs was coated with $B$. thuringiensis proteins and subsequently fed to C. carnea larvae (Croft 1990, Sims 1995). However, because C. carnea suck out the egg contents without ingesting the shells, they probably ingested little or no $B$. thuringiensis protein. In another study, $B$. thuringiensis-containing pollen of transgenic plants was provided to test for side effects of CrylAb on C. carnea larvae (Pilcher et al. 1997). However, concentrations of CrylAb in pollen are low (2.57-2.94 $\mu \mathrm{mg} / \mathrm{g}$ dry weight) compared with that of leaves (Perlak et al. 1990, Koziel et al. 1993, Fearing et al. 1997) and predaceous C. carnea larvae feed only to a very limited extent if at all on pollen.

Mass-rearing techniques of $C$. carnea typically involve either live prey, such as aphids, or insect eggs such as Ephestia kuehniella (Hübner) or S. cerealella (Ridgway et al. 1970, Hassan 1975, Morrison et al. 1975, Morrison and Ridgway 1976). In an effort to improve efficient mass-production techniques for biocontrol purposes, attempts have been made to develop an artificial diet (AD) for chrysopid larvae. The larvae were either supplied with an artificial diet soaked into a sponge, droplets of an artificial diet, or an artificial diet encapsulated into paraffin spheres (Hagen and Tassan 1965, Vanderzant 1969, Bigler et al. 1976, Martin et al. 1978). The encapsulation technique of a liquid artificial diet into tiny paraffin spheres has been markedly improved and mechanized by a German company
(STB Control, Aarbergen, Germany) and is being successfully used by this company for mass rearing of $C$. carnea as a biocontrol agent. Our study reports on testing a $B$. thuringiensis protein directly against $C$. carnea larvae by using an artificial diet (encapsulated in paraffin spheres). The specific objectives were to investigate the impact of CrylAb-toxin on mortality and development of C. carnea larvae and to determine the suitability of the paraffin encapsulated, artificial diet for feeding tests with $C$. camea larvae of $B$. thuringiensis proteins that need to be ingested to be effective.

\section{Materials and Methods}

Insects. C. carmea larvae from the permanent laboratory colony of our institute were used. C. carnea larvae have been maintained using pea aphids Acyrthosiphon pisum (Harris) and E. kuehniella eggs since 1988 without any introduction of field-collected insects. Nonpredaceous adults were kept on a mixture of yeast, honey, and water. Rearing conditions were $22-25^{\circ} \mathrm{C}, 70 \% \mathrm{RH}$, and a photoperiod of $16: 8$ ( $\left.\mathrm{L}: \mathrm{D}\right) \mathrm{h}$. Neonate larvae of Ostrinia nubilalis (Hübner) also were obtained from our permanent laboratory colony that has been maintained on a meridic diet for several generations under conditions similar to those described above for C. carnea.

Bacillus thuringiensis Proteins and Artificial Diet. The CrylAb protoxin from B. thuringiensis subsp. kurstaki HD-1 was expressed as a single gene product in Escherichia coli (Masson et al. 1990). Inclusion bodies containing CrylAb protoxin were dissolved and trypsinized and the CrylAb toxin was isolated using high-performance liquid chromatography (HPLC) (Pusztai-Carey et al. 1994). Isolated material was lyophilyzed. The artificial diet consisted of paraffin spheres of $\approx 1 \mathrm{~mm}$ in diameter containing a liquid diet specifically developed for optimal nutrition of C. carnea larvae (Schwenk and Tygges, STB Control, Aarbergen, Germany). CrylAb toxin was solubilized in 15 $\mathrm{ml}$ of double distilled water and added to the liquid diet before encapsulation to make a final concentration of $100 \mu \mathrm{g} / \mathrm{ml}$ of diet. The biological activity of the encapsulated CrylAb toxin-containing diet was verified by conducting a series of 5 bioassays during the course of the experiment by using a CrylAb-susceptible target pest species, $O$. nubilalis.

Feeding Trials. C. carnea larvae can use the encapsulated diet only after they have reached the 2nd instar and their mouthparts are strong enough to penetrate the skins of the paraffin spheres. Therefore, 2 different methods were used to rear chrysopid larvae through the 1st instar. Once chrysopid larvae had reached the 2 nd instar, all of them received paraffinencapsulated artificial diet with or without CrylAb toxin ( $\pm \mathrm{Bt} / \mathrm{AD})$, respectively. Table 1 provides an overview of all applied treatments. For method 1, each lst instar was supplied with one $0.5-\mathrm{cm}^{3}$ polyethylene foam cube soaked in nonencapsulated liquid diet either without $B$. thuringiensis (treatment $1,-B$ t/AD) or with CrylAb toxin added at a concentration of 100 
Table 1. Overview of treaunents applied in feeding trials with C. carnea larvae

\begin{tabular}{ccl}
\hline Treatment & $\begin{array}{c}\mathrm{Bt} \\
\text { exposure }\end{array}$ & \multicolumn{1}{c}{ Diet } \\
\hline 1 & $-\mathrm{Bt}$ & Artificial diet (AD) only (method 1) \\
2 & $+\mathrm{Bt}$ & Artificial diet (AD) only (method 1) \\
3 & $-\mathrm{Bt}$ & E. kuehniella eggs/artificial diet (method 2) \\
4 & $+\mathrm{Bt}$ & E. kuehniella eggs/artificial diet (method 2) \\
5 & $-\mathrm{Bt}$ & E. kuehniella eggs only \\
\hline
\end{tabular}

$\mu \mathrm{g} / \mathrm{ml}$ of diet (treatment $2,+\mathrm{Bt} / \mathrm{AD}$ ). Hence, larvae raised according to treatment 2 were exposed to $B$. thuringiensis toxin during their entire larval stage ( $\mathrm{Ta}-$ ble 1), whereas in the corresponding control (treatment 1), the equivalent amount of double distilled water was added. Diet-soaked foam cubes were replaced daily until larvae reached the 2nd instar. For method 2, E. kuehniella eggs attached to moistened pieces of cardboard paper (1 by $0.5 \mathrm{~cm}$ ) were provided as food during 1st instars. One egg-covered cardboard piece was added to each rearing container with Ist instars. Consequently, C. carnea reared according to treatment 4 (eggs/ + Bt/AD) were exposed to Cry $1 \mathrm{Ab}$ toxin only during $2 \mathrm{nd}$ and 3 rd instar (Table 1), whereas the corresponding control (i.e., treatment 3; eggs/-Bt/AD) did not receive any Cryl Ab toxin. In addition to the 4 treatments just described, a reference treatment was included where C. carnea larvae were raised exclusively on E. kuehniella eggs (treatment 5, eggs).

C. carnea larvae were kept individually in open-top plastic cups ( 5 by $6 \mathrm{~cm}$ diameter), the margins of which were coated with fluon (Whitford $\mathrm{GmbH}$, Limburg, Germany) that prevented the larvae from escaping. Thirty 1-d-old C. carnea larvae were used per treatment. The experiment was repeated 5 times. Thus, a total of 750 chrysopid larvae was examined. Stage-specific mortality and developmental time were monitored daily. Developmental stage could reliably be identified by finding the exuviae after each molt. Experiments were carried out in a controlled-environment chamber at fluctuating temperatures $\left(25^{\circ} \mathrm{C}\right.$ for $10 \mathrm{~h}$ during photophase and $20^{\circ} \mathrm{C}$ for the remaining $14 \mathrm{~h}$ ) averaging $22^{\circ} \mathrm{C} / \mathrm{d}, 70 \% \mathrm{RH}$ and a photoperiod of 16:8 (L:D) h.

For the statistical analyses of stage-specific mortality, a logistic regression was carried out calculating the proportion of individuals that died during each instar and accounting for the binomial probability distribution of mortality data. A model was used that tested for significant replication effects and partitioned the treatments into 2 main effects (i.e., B. thuringiensis treatment and type of diet, and their interaction effect). Analyses were performed using the GENMOD procedure of the SAS statistical package, including a DSCALE and Type 1 and 3 statement producing the appropriate F-statistics (SAS Institute 1996). In addition, mean mortality and standard errors were determined and means were compared by carrying out the MEANS procedure, including a LSMEANS statement (SAS Institute 1996).
Stage-specific developmental times were determined in numbers of days required to complete each instar. In addition, mortality and developmental time from 1st instar to adult (L1-A) (=entire immature) was determined. For the statistical analyses, a regular analysis of variance (ANOVA) was carried out testing for significant replication and treatment effects. A model was used that partitioned the treatments into 2 main effects (i.e., B. thuringiensis treatment and type of diet, and their interaction effect). Analyses were performed using the general linear model (GLM) procedure of the SAS statistical package, including a LSMEANS statement (SAS Institute 1996).

Bioassays of CrylAb with $O$. nubilalis Larvae. To determine if CrylAb toxin was still biologically active after being added into the artificial diet, $3 \mathrm{~g}$ of crushed diet containing CrylAb toxin or CrylAb toxin-free diet was each mixed into $3 \mathrm{~g}$ of standard meridic diet used for rearing the permanent laboratory colony of $O$. nubilalis. In addition, as a reference, freeze-dried CrylAb-toxin dissolved in double distilled water was mixed into meridic diet at a concentration of $100 \mu \mathrm{g}$ of toxin per gram of meridic diet. For the control, an equivalent amount of double distilled water was mixed into the meridic diet. This resulted in a total of 4 treatments. Approximately $500 \mathrm{mg}$ of the respective treated meridic diet was filled into each of 10 vials (1.2 $\mathrm{cm}$ diameter by $7.5 \mathrm{~cm}$ length) per treatment. Four neonate $O$. nubilalis larvae were placed into each vial and subsequently sealed with perforated plastic lids to allow air circulation ( $=40$ larvae per treatment). Bioassays were replicated 5 times and were performed concurrently with the $C$. carnea feeding trials. Therefore, a total of $800 O$. nubilalis larvae was examined. Numbers of dead larvae were recorded after 4 or $5 \mathrm{~d}$. For the statistical analyses of mortality, a logistic regression was carried out calculating the proportion of individuals that died accounting for the binomial probability distribution of mortality data. A model was used that tested for significant replication and treatment effects. Analyses were performed using the GENMOD procedure of the SAS statistical package, including a DSCALE and Type 1 and 3 statement producing the appropriate $F$-statistics (SAS Institute 1996). In addition, mean mortality and standard errors were determined and means were compared by carrying out the MEANS procedure and a LSD test of the SAS statistical package, respectively (SAS Institute 1996).

\section{Results}

CrylAb Effects. Except during the 1st instar, overall mean mortality of $C$. carnea was consistently higher when raised on Cryl $\mathrm{Ab}$ toxin-containing than on $B$. thuringiensis-free diet (Fig. I b-f). Mortality during the lst instar was low and no significant differences were observed, despite the early exposure of C. camea larvae to CrylAb toxin when raised on artificial diet only (+Bt/AD) (Fig. 1a). Highest mortality occurred during 2 nd instar and the pupal stage (Fig. $1 \mathrm{~b}$ and e). In the logistic regression analyses, this resulted in 

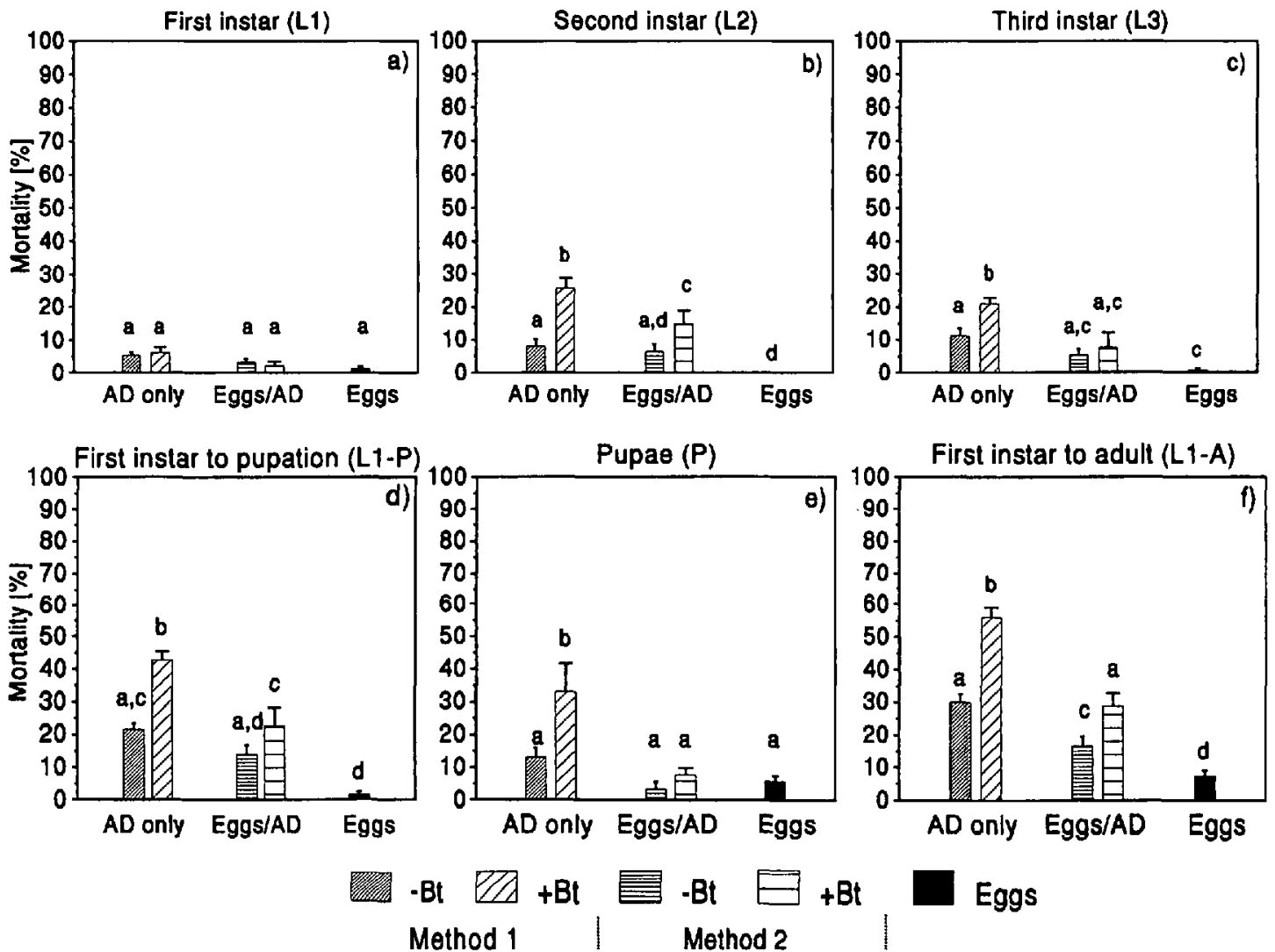

Fig. 1. Stage-specific mean mortality (\%) and standard error of immature C. carnea feeding on different types of CrylAb toxin-containing and CrylAb toxin-free diets (a) 1st instars, (b) 2nd instars, (c) 3rd instars, (d) total larval stage (L1-P), (e) pupal stage, and (f) total immature life stage (L1-A). Means with different letters are significantly different at $P=0.05$ significance level (LSMEANS), AD, artificial diet (method I); eggs/AD, E. kuehniella eggs during lst instar, artificial diet during 2 nd and 3rd instar (method 2); eggs, E. kuehniella eggs only.

significant $B$. thuringiensis main effects for all stages, except 1 st and $3 \mathrm{rd}$ instars $\left\langle F_{12}=23.87 ; \mathrm{df}=1,16 ; P=\right.$ $0.0002 ; F_{\mathrm{L} 1-\mathrm{P}}=19.10 ; \mathrm{df}=1,16 ; P=0.0005 ; F_{\mathrm{P}}=6.54$; df $=1,16 ; P=0.0211 ; F_{\mathrm{L} 1-\mathrm{A}}=39.70 ; \mathrm{df}=1,16 ; P=$ $0.0001)$.

Detailed analyses revealed that mortality was highest for C. carnea larvae that received CrylAb toxincontaining diet since the 1st instar (+Bt/AD) (Fig. la-f). Total mortality of 43 and $57 \%$ was recorded for C. carnea continuously reared on CrylAb toxin diet (+Bt/AD) until pupation (Ll-P) and adult eclosion (L1-A), respectively. Significantly fewer larvae died until pupation (21\%) and adult eclosion (30\%) in the respective CrylAb toxin-free control (-Bt/AD) (Fig. Id and $\mathrm{f}$ ). Larvae receiving CrylAb toxin diet after they had reached the 2 nd instar (+Bt/Eggs/AD) exhibited significantly lower mortality than larvae continuously fed CrylAb toxin diet ( $+\mathrm{Bt} / \mathrm{AD})$. Twentythree and $29 \%$ of the larvae died before pupation (Ll-P) and adult eclosion (L1-A), respectively, when exposed to CrylAb toxin later during larval development ( +Bt/Eggs/AD) (Figs. 1d and f). Although mortality was consistently higher among CrylAb toxintreated than untreated $C$. carnea larvae when they received artificial diet after reaching the 2 nd instar (method 2), this difference was significant only for 2nd instars (Fig. 1b); and also resulted in a significant difference for total larval (L1-P) and entire immature life stage (L1-A) (Fig. 1d and f).

Similar to mortality, there were no significant differences during the 1st instar in developmental time between C. camea larvae fed Cryl Ab toxin-containing and CrylAb toxin-free diet despite early exposure of C. carnea larvae to CrylAb toxin when raised continuously on artificial diet (+Bt/AD) (Fig. 2a). But during the 2nd and 3rd instar and the pupal stage, mean developmental times were significantly $(P<0.05)$ prolonged relative to the corresponding control (-Bt/AD) when larvae were exposed to CrylAb toxin-diet ( $+B t / A D)$ since the 1st instar. This resulted in significant $B$. thuringiensis main effects in the ANOVA for second instars $\left(F_{\mathrm{L} .2}=6.18 ; \mathrm{df}=1,16 ; P=0.024\right.$ ) and pupae $\left(F_{\mathrm{P}}=10.51\right.$; df $\left.=1,16 ; P=0.005\right)$ and marginally significant $B$. thuringiensis main effect for third instars $\left(F_{\mathrm{L} 3}=4.25\right.$; $\mathrm{df}=1,16 ; P=0.055$ ) (Fig. $2 b, c$, and e). However, for total developmental time until pupation (L1-P) and adult eclosion (L1-A) these differences were insignificant (Fig. $2 \mathrm{~d}$ and f). No 

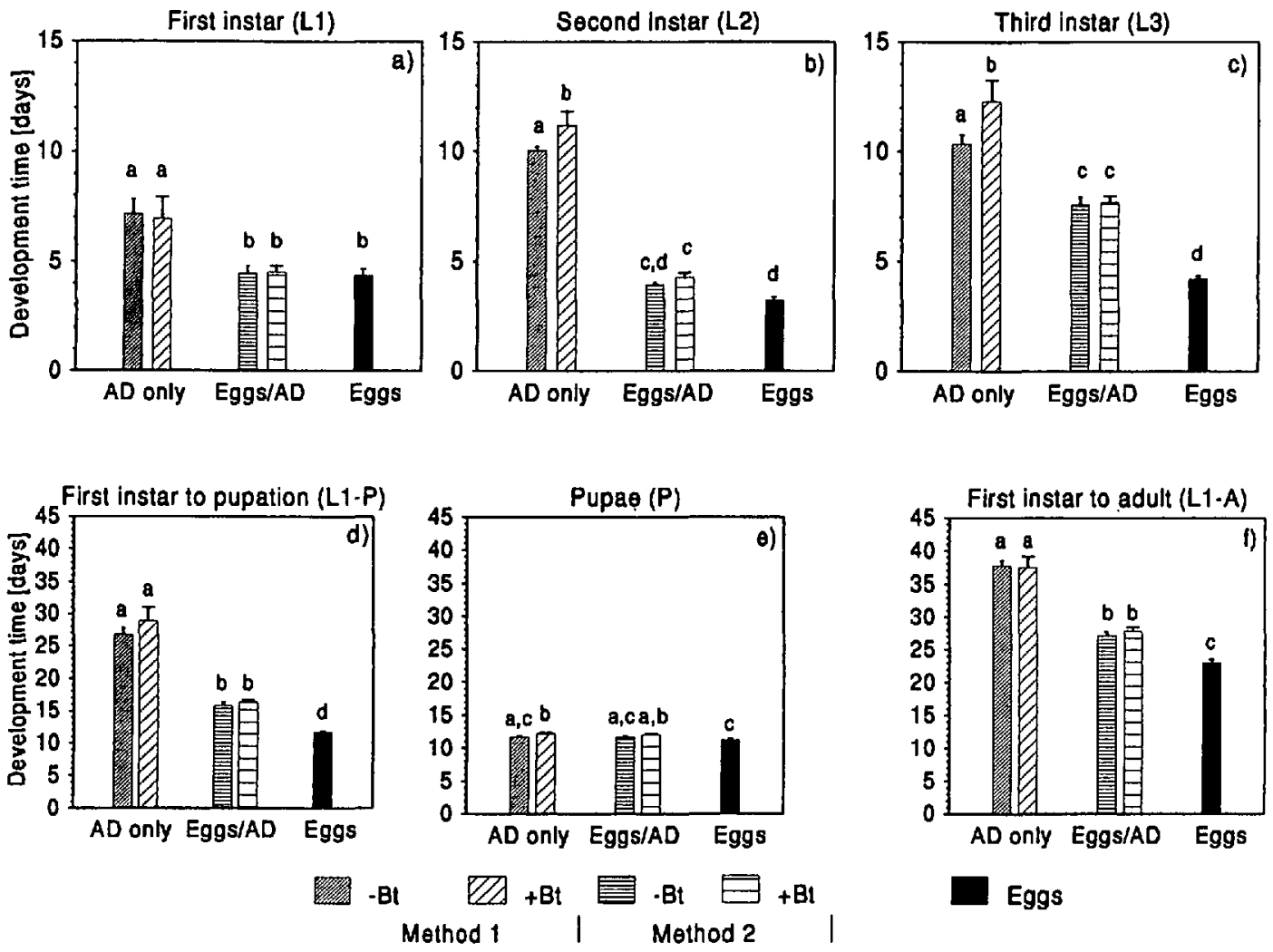

Fig. 2. Stage-specific mean development time (days) and standard error of immature C. camea feeding on different types of CrylAb toxin-containing and CrylAb toxin-free diets (a) 1st instars, (b) 2nd instars, (c) 3rd instars, (d) total larval stage (L1-P), (e) pupal stage, and ( $f$ ) total immature life stage (L1-A). Means with different letters are significantly different at $P=0.05$ significance level (LSMEANS), AD, artificial diet (method 1); eggs/AD, E. kuehniella eggs during lst instar, artificial diet during 2 nd and 3rd instar (method 2); eggs, E. kuehniella eggs only.

significant differences in developmental time between larvae fed CrylAb toxin-containing or CrylAb toxinfree diet were observed at any time for C. camea that received the artificial diet after they had reached the 2nd instar (method 2) (Fig. 2 b-f). For both mortality and developmental time, no interaction between CrylAb toxin treatment and type of diet provided could be observed.

Diet Effects. Except during first instar, there was always a significant diet main effect in the statistical analyses of mortality $\left(F_{\mathrm{L} 2}=11.76 ; \mathrm{df}=2,16 ; P=\right.$ $0.0007 ; F_{\mathrm{L} 3}=9.35 ; \mathrm{df}=2,16 ; P=0.002 ; F_{\mathrm{L} 1-\mathrm{P}}=24.19$; $\mathrm{df}=2,16 ; P=0.0001 ; F_{\mathrm{P}}=7.85 ; \mathrm{df}=1,16 ; P=0.0042$; $\left.F_{1.1-\mathrm{A}}=39.07 ; \mathrm{df}=2,16 ; P=0.0001\right)$. Detailed analyses showed that until pupation, this was due to significantly lower mortality for larvae that were raised exclusively on E. kuehniella eggs. No statistical differences in levels of mortality were observed until pupation between larvae raised on CrylAb toxin-free diet according to method 1 (-Bt/AD) or method 2 (-Bt/E/AD) (Fig, la-d). But mortality of C. carnea pupae was higher when their larvae had been supplied untreated artificial diet since the lst instar ( $-\mathrm{Bt} / \mathrm{AD})$ than when they received artificial diet after reaching the 2nd instar ( $-\mathrm{Bt} / \mathrm{E} / \mathrm{AD}$ ) (Fig. 1e). This resulted in significantly higher total mortality from lst instar to adult eclosion (L1-A) of C. carnea reared continuously on artificial diet (-Bt/AD) but did not exceed $30 \%$ (Fig. 1f). Lowest total mortality (L1-A) was observed for C. carnea raised exclusively on $E$. kuehniella eggs (8\%) (Fig. 1f). Total immature mortality (L1-A) of C. camea provided with a combination of E. kuehniella eggs and untreated artificial diet (method 2) was intermediate to the other 2 types of diet (17\%).

There were also significant differences in developmental time for most life stages between larvae that were raised on the different types of diet, except pupae $\left(F_{\mathrm{Ll}}=33.38 ; \mathrm{df}=2,16 ; P=0.001 ; F_{\mathrm{L} 2}=288.97\right.$; $\mathrm{df}=2,16 ; P=0.001 ; F_{\mathrm{L} 3}=60.1 ; \mathrm{df}=2,16 ; P=0.001$; $F_{\mathrm{L} 1-\mathrm{P}}=141.06 ; \mathrm{df}=2,16 ; P=0.001 ; F_{\mathrm{L} 1-\mathrm{A}}=146.86 ; \mathrm{df}=$ $2,16 ; P=0.001)$. In contrast to mortality, only the developmental time of $C$. carnea pupae did not differ with respect to diet (Fig. 2e). C. carnea that received E. kuehniella eggs during the 1st instar and that were supplied untreated artificial diet after reaching the 2nd instar (-Bt/E/AD) developed significantly faster than larvae reared continuously on untreated artificial diet ( $-\mathrm{Bt} / \mathrm{AD}$ ) who exhibited the slowest development. Larvae receiving untreated artificial diet after reaching the 2 nd instar $(-\mathrm{Bt} / \mathrm{E} / \mathrm{AD})$ required on av- 
Table 2. Resulte of bionsgays with 1 st-instar $O$. nubilalis larvae monitoring activity of CrylAb-containing paraffine spheres

\begin{tabular}{ccccc}
\hline \multirow{2}{*}{ Run } & \multicolumn{4}{c}{ Treatment } \\
\cline { 2 - 5 } & \multicolumn{1}{c}{1} & \multicolumn{1}{c}{$\mathrm{2}$} & 3 & 4 \\
\hline 1 & $100 \pm 0 \mathrm{a}$ & $20 \pm 8.16 \mathrm{~b}$ & $97.5 \pm 2.5 \mathrm{a}$ & $25 \pm 7.45 \mathrm{~b}$ \\
2 & $100 \pm 0 \mathrm{a}$ & $32.5 \pm 8.38 \mathrm{~b}$ & $100 \pm 0 \mathrm{a}$ & $27.5 \pm 8.70 \mathrm{~b}$ \\
3 & $100 \pm 0 \mathrm{a}$ & $22.5 \pm 6.92 \mathrm{~b}$ & $97.5 \pm 2.5 \mathrm{a}$ & $32.5 \pm 11.21 \mathrm{~b}$ \\
4 & $100 \pm 0 \mathrm{a}$ & $30 \pm 8.98 \mathrm{~b}$ & $100 \pm 0 \mathrm{a}$ & $10 \pm 5.53 \mathrm{~b}$ \\
5 & $100 \pm 0 \mathrm{a}$ & $15 \pm 5.53 \mathrm{~b}$ & $100 \pm 0 \mathrm{a}$ & $37.5 \pm 10.04 \mathrm{~b}$ \\
\hline
\end{tabular}

Treatments: 1, CrylAb toxin-containing encapsulated diet mixed into meridic diet; 2, CrylAb toxin-free encapsulated diet mixed into meridic diet; 3 , purified Cryl Ab toxin-solution mixed into meridic diet (100 $\mathrm{g} / \mathrm{g}$ of diet); and 4, double distilled water mixed into meridic diet, $n=10$. Means with the same letter in a row are not significantly different (LSD).

erage 16 and $27.5 \mathrm{~d}$ until pupation and adult eclosion, respectively (Fig. $2 \mathrm{~d}$ and $\mathrm{f}$ ), whereas $C$. carnea raised on artificial diet since the lst instar needed on average $28 \mathrm{~d}$ until pupation and $37.5 \mathrm{~d}$ until adult eclosion (Fig. $2 \mathrm{~d}$ and f). The shortest developmental time was noted for $C$. carnea that were exclusively fed E. kuehniella eggs. They required 12 and $23 \mathrm{~d}$ until pupation and adult eclosion, respectively (Fig. $2 \mathrm{~d}$ and $\mathrm{f}$ ).

Ostrinia nubilalis Bioassays. The results of the bioassays using one of the primary target pests of CrylAbexpressing transgenic plants, $O$. nubilalis, confirmed the continuous biological activity of the paraffin-encapsulated artificial diet containing $\mathrm{CrylAb}$ toxin used in the experiments (Table 2). Mortality of O. nubilalis larvae fed with CrylAb toxin-containing diet was always significantly higher than when $O$. nubilalis larvae received CrylAb toxin-free diet, regardless whether crushed paraffin spheres were mixed into the meridic diet or into purified toxin and water ( $F_{\text {Treatment }}=$ 2087.51; df $=3,192 ; P=0.0001$ ) (Table 2). Averaged across replications, mortality of 1st-instar $O$. nubilalis was 100 and $99 \%$ when crushed CrylAb toxin-paraffin spheres or purified, nonencapsulated CrylAb toxintoxin solution was mixed into the meridic diet, respectively, compared with 24 and $26.5 \%$ mortality for the respective controls.

\section{Discussion}

Continuous exposure to $\mathrm{Cryl} \mathrm{Ab}$ toxin resulted in significantly higher mortality of immature C. carmea. Fifty-seven percent of $C$. carnea exposed to the $B$. thuringiensis protein since the 1st instar died during immature development before adult eclosion whereas mortality was only $30 \%$ for untreated C. camea in the respective control. This demonstrates a sensitivity of this species to CrylAb toxin at a concentration of 100 $\mu \mathrm{g} / \mathrm{ml}$ of diet. The same pattern was observed when C. camea was exposed to CrylAb toxin after reaching the 2nd instar, although overall mortality was lower and not always statistically significant. Total immature mortality was again almost twice as high in the CrylAb toxin treatment as in the untreated control. Despite this higher mortality, only very small to no effects due to CrylAb toxin could be observed for the total de- velopmental time to pupation or adult eclosion. During the life stages in which mortality occurred (2nd and 3rd instar, and pupae), a slightly prolonged developmental time was observed only for $C$. carnea raised on CrylAb toxin-containing artificial diet since the lst instar (method 1), but not for those exposed to CrylAb toxin later during larval development (method 2). As a result of the CrylAb toxin-treatment, $C$. carnea larvae and pupae that were affected by the CrylAb toxin died before completing their immature life stage. Surviving, unaffected C. camea developed at rates similar to those in the untreated control.

These results support the findings from our previous study where we fed susceptible and nonsusceptible lepidopteran herbivores raised on transgenic, CrylAb-expressing corn plants to $C$. camea larvae (Hilbeck et al. 1998). Mortality was also significantly higher for C. carnea raised on CrylAb toxin-fed prey whereas total immature developmental time was unaffected. From this, we concluded that total developmental time until pupation or adult eclosion is not an appropriate parameter for detecting CrylAb toxin effects.

Interestingly, mortality levels observed in the experiments described herein were similar to those observed in our previous study by using the transgenic $B$. thuringiensis corn variety by Novartis (Hilbeck et al. 1998). For this corn cultivar, the concentration of CrylAb protein did not exceed $4 \mu \mathrm{g} / \mathrm{g}$ of fresh weight in leaves and was substantially lower in all other tissues analyzed (Fearing et al. 1997). Consequently, perhaps the amount of CrylAb toxin passed on to C. carnea by its prey in our earlier studies using transgenic $B$. th $u$ ringiensis-corn was much smaller than the amount present in the paraffin-encapsulated artificial diet containing Cry $1 \mathrm{Ab}$ toxin at a concentration of $100 \mu \mathrm{g} / \mathrm{ml}$ (Hilbeck et al. 1998). Yet, mortality levels in both studies were similar. Furthermore, most of the mortality of $C$. carnea occurred during the 1st and 2nd instar in our companion study whereas in the current study, increased mortality was observed for all immature life stages, except lst instars. To determine the reasons for this, further investigations are required. It may be associated with the biochemical processing of CrylAb toxin inside the herbivore's gut, thereby, retaining and perhaps even increasing its activity toward C. carnea. Interestingly, Haider et al. (1986) reported that the insect specificity of $B$. thuringiensis var. aizawai $\mathrm{ICl}$ could be altered depending on which digestive fluids processed the proteins. They showed that processing of $B$. thuringiensis proteins by Pieris brassicae gut enzymes resulted in a $55 \mathrm{kDa}$ protein that only was toxic to lepidopteran cell lines, whereas with Aedes aegypti gut extracts, the resulting $52-\mathrm{kDa}$ protein only was toxic to mosquito cell lines and a Spodoptera frugiperda cell line. Therefore, the hypothesis that the processing of CrylAb toxin within the herbivore host to a form more toxic to $C$. camea has merit and warrants further investigation. Because a current and future trend in plant molecular biology is to increase expression levels of $B$. thuringiensis in plants, choosing a comparatively high concentration is justi- 
fied. The most dramatic example of this trend is the expression of CrylAc in tobacco chloroplasts where McBride et al. (1995) reported that an unprecedented $3-5 \%$ of total soluble protein in tobacco leaves was CrylAc protoxin.

The observed effects may further be related to the modified form of $B$. thuringiensis protein in transgenic plants in contrast to $B$. thuringiensis insecticides that were mainly used for nontarget studies in the past (Croft 1990). In formulations, B. thuringiensis proteins are typically present as a mixture of crystals and spores (Feitelson et al. 1992), B. thuringiensis corn produces a $69-\mathrm{kDa}$ portion of the native $130-\mathrm{kDa}$ Cryl Ab protoxin. This is a relatively small protoxin that is comprised of $\approx 620-648$ amino acids (Koziel et al. 1993). Inside the insect gut only a small fragment of $\approx 4 \mathrm{kDa}$ must be further cleaved (e.g., by trypsin) to produce the fully activated, trypsinized $65-\mathrm{kDa}$ toxin. Consequently, no crystal solubilization and almost no protoxin-toxin conversion is necessary within the insect gut. Both processes are important for the specificity of B. thuringiensis compounds (Goldburg and Tjaden 1990). Thus, selectivity and biochemical processing may be altered in a herbivore. For example, both $S$. littoralis and $S$. exigua are $>2$ times more susceptible to CrylAb and CrylAc toxins, respectively, than to their respective protoxins (MacIntosh et al. 1990; Moar et al. 1990; A.H., unpublished data).

No mortality or only sublethal side effects of $B$. thuringiensis proteins on $C$. carnea have been reported (Croft 1990, Sims 1995, Pilcher et al. 1997). One reason may be that there was a lack of an appropriate bioassay system whereby $C$. carnea larvae could actually ingest $B$. thuringiensis proteins. Previous studies investigating direct effects of $B$. thuringiensis on $C$. camea were carried out, for example, by coating $S$. cerealella eggs with the respective $B$. thuringiensis-preparation (Croft 1990, Sims 1995). But due to the sucking feeding behavior of chrysopid larvae, it is likely that only little or no B. thuringiensis preparation actually was ingested in these trials. The paraffin-encapsulated diet used in our studies represents a method for studying the direct effects of purified, water-soluble $B$. thuringiensis proteins on immature C. carnea.

Although developmental time was prolonged for $C$. carnea larvae reared on artificial diet only in our study, control mortality over a mean of $37 \mathrm{~d}$ remained acceptably low (AD/-Bt, 30\%). Sims (1995) reported $23 \%$ control mortality for $C$. camea after only $9 \mathrm{~d}$ by using a $S$. cerealella egg-based bioassay and $30 \%$ control mortality for another hymenopteran natural enemy after only $9 \mathrm{~d}$. However, during the first $7 \mathrm{~d}$ of our bioassay period (end of 1 st instar) total mean control mortality was well below $10 \%$ in all treatments, which is typical of many lepidopteran bioassays (MacIntosh et al. 1990, Moar et al. 1995). Mortality was particularly low in the E. kuehniella treatment where in contrast to Sims (1995), total mortality over a period of $20 \mathrm{~d}$ was only $8 \%$. Our data showed that exposure to CrylAb toxin during the 1st instar was important for total mortality. Information on overall mortality and sensitivity of $C$. carnea was lost when exposing $C$. carnea larvae to CrylAb toxin after they had reached the 2 nd instar. Therefore, we conclude that providing artificial diet continuously according to method 1 , including 1 st instars, is a suitable method to detect the direct effects of $B$. thuringiensis or other insecticidal substances (affecting intestinal processes of insects) on immature $C$. carnea fitness. But it is acknowledged that a population suffering $30 \%$ mortality may be stressed, which may result in potentially enhanced responses.

Another reason for not finding effects of $B$. thuringiensis on C. carnea in the past may be that in previous studies chrysopid larvae were exposed to $B$. thuringiensis proteins only for a portion of their whole larval period. For example, Pilcher et al. (1997) and Sims (1995) exposed C. camea larvae to CrylAb-pollen or CrylAc-coated S. cerealella eggs for a total of 3 and $9 \mathrm{~d}$, respectively. Similarly, Salama et al. (1982) provided neonate $B$. thuringiensis var, entomocidus-fed $S$. littoralis larvae to $C$. carnea larvae only for $7 \mathrm{~d}$. In all studies, untreated food was supplied afterwards, which may have allowed them to recover from a potential long-term effect. As our data demonstrate, increased mortality occurred during all stages, except the 1st instar. If our experiments had been terminated after 3 and $9 \mathrm{~d}$, much if not all of the mortality would have been missed depending on what period of the larval development would have been chosen. In the past, when $B$. thuringiensis formulations were used as an insecticide, the short-term approach in nontarget trials was appropriate. However, in the future, $B$. thuringiensis proteins will be common in the agroecosystem where they may be present for several weeks or months. Hence, natural enemies will encounter $B$. thuringiensis-containing prey or hosts frequently, in particular, in areas where different $B$. thuringiensis crop plants are grown either next to each other or following each other. Therefore, long-term bioassays with natural enemies are more realistic indicators of possible population-level effects in a system with transgenic plants. But obviously, trials investigating predation efficiency and predator performance under field conditions are necessary before conclusions regarding the potential ecological relevance of the results presented in our paper can be drawn.

The results of our current laboratory experiments and those of Hilbeck et al. (1998) support the hypothesis that the selectivity of $B$. thuringiensis plants cannot simply be deduced from the record of safety of $B$. thuringiensis insecticides but needs to be verified in trials that account for their modified form of release in transgenic plants and their prolonged presence in the plants. For the long-term use of these new plants, their agroecological safety is as essential as is pest resistance development, particularly because performance and fitness of natural enemies in $B$. thuringiensis crop fields also may affect pest resistance development (Gould et al. 1991, Johnson et al. 1997). B. thuringiensis-based insecticides and transgenic plants are still more environmentally friendly than most if not all chemical insecticides. However, our results suggest that a closer look at the impact of $B$. thuringiensis on beneficial insects may be necessary before a complete IPM- 
biocontrol system that is based on $B$. thuringiensis transgenic plants is initiated.

\section{Acknowledgments}

We gratefully acknowledge the technical assistance of S Bosshard, M. Sbaiz, S. Wagen, and M. Waldburger. We are thankful to R. Schwenk and S. Tygges (STB Control, Schaltenbach 1, D-65326 Aarbergen 3, Germany) for providing the artificial diet. This research was partially funded by the Swiss National Science Foundation, Priority Program Biotechnology, Module 5B Biosafety, Grant no. 5002-42598.

\section{References Cited}

Bigler, F., A. Ferran, and J.-P. Lyon. 1976. L'élevage larvaire de deux prédateurs aphidiphages (Chrysopa carnea Steph., Chrysopa perla L.) a l'aide de différents milieux artificiels. Ann. Zool. Ecol. Anim. 8: 551-558.

Croft, B. A. 1990. Arthropod biological control agents and pesticides. Wiley, New York.

Fearing, P. L., D. Brown, D. Vlachos, M. Meghji, and L. Privalle. 1997. Quantitative analysis of CryIA(b) ex pression in Bt maize plants, tissues, and silage and stability of expression over successive generations. Mol. Breeding 3: $169-176$.

Feitelson, J. S., J. Payne, and L. Kim. 1992. Bacillus thuringiensis: Insects and beyond. Bio/Technology 10: 271-275.

Flexner, J. L., B. Lighthart, and B. A. Croft. 1986. The effects of microbial pesticides on non-target, beneficial arthropods. Agric. Ecosys. Environ. 16: 203-254.

Fujimoto, H., K. Itoh, M. Yamamoto, J. Kyozuka, and K. Shimamoto. 1993. Insect resistant rice generated by introduction of a modified $\delta \mathrm{d}$-endotoxin gene of Bacillus thuringiensis. BioTechnology 11: 1151-1155.

Goldburg, R. J., and G. Tjaden. 1990. Are B.T.K. plants really safe to eat? BioTechnology 8: 1011-1015.

Gould, F., G. G. Kennedy, and M. T. Johnson. 1991. Effects of natural enemies on the rate of herbivore adaptation to resistant host plants. Entomol. Exp. Appl. 58: 1-14.

Haider, M. Z., B. H. Knowles, and D. J. Ellar. 1986. Specificity of Bacillus thuringiensis var. colmeri insecticidal delta-endotoxin is determined by differential proteolytic processing of the protoxin by larval gut proteases. Eur. J. Biochem. 156: 531-540.

Hagen, D. S., and R. L. Tassan. 1965. A method of providing artificial diets to Chrysopa larvae. J. Econ. Entomol. 58: 999-1000.

Hassan, S. A. 1975. Über die Massenzucht von Chrysopa camea Steph. (Neuroptera, Chrysopidae). Z. Angew. Entomol. $79:$ : $310-315$.

Hilbeck, A., M. Baumgartner, P. M. Fried, and F. Bigler. 1998. Effects of transgenic Bacillus thuringiensis-cornfed prey on mortality and development time of immature Chrysoperla carnea (Neuroptera: Chrysopidae). Environ. Entomol. 27: 480-487.

Jepson, P. C., B. A. Croft, and G. E. Pratt. 1994. Test systems to determine the ecological risks posed by toxin release from Bacillus thuringiensis genes in crop plants. Mol. Ecol. 3: $81-89$.

Johnson, M. T., F. Gould, and G. G. Kennedy, 1997. Effects of natural enemies on relative fitness of Heliothis virescens genotypes adapted and not adapted to resistant host plants. Entomol. Exp. Appl. 82: 219-230.

Koziel, M. G., G. L. Beland, C. Bowman, N. B. Carozzi, R. Crenshaw, L. Crossland, J. Dawson, N. Desai, M. Hill, S.
Kadwell, K. Launis, and others. 1993. Field performance of elite transgenic maize plants expressing an insecticidal protein derived from Bacillus thuringiensis. BioTechnology 11: 194-200.

MacIntosh S. C., T. B. Stone, S. R. Sims, P. L. Hunst, J. T. Greenplate, P. G. Marrone, F. J. Perlak, D. A. Fischhoff, and R. L. Fuchs, 1990. Specificity and efficacy of purified Bacillus thuringiensis proteins against agronomically important insects. J. Invertebr. Pathol. 56: 258266.

Martin, P. B., R. L. Ridgway, and C. E. Schuetze. 1978. Physical and biological evaluation of an encapsulated diet for rearing Chrysopa carnea. Fla. Entomol. 61: 145-1.52.

Masson, L., G. Prefontaine, L. Peloquin, P.C.K. Lau, and R. Brousseau. 1990. Comparative analysis of the individual protoxin components in $\mathrm{P} 1$ crystals of Bacillus thuringiensis subsp. kurstaki isolates NRD-12 and HD-1. Biochem. J. 269: $507-512$

McBride, K. E., Z. Svab, D. J. Schaaf, P. S. Hogan, D. M. Stalker, and P. Maliga. 1995. Amplification of a chimeric Bacillus gene in chloroplasts leads to an extraordinary level of an insecticidal protein in tobacco. BioTechnology 13: 362-365.

Melin, B. E., and E. M. Cozzi. 1989. Safety to nontarget invertebrates of lepidopteran strains of Bacillus thuringiensis and their $\beta$-exotoxins. In M. Laird, L. A. Lacey, and E. W. Davidson [eds.], Safety of microbial insecticides. CRC, Boca Raton, FL

Mellon, M., and J. Rissler, 1998. Now or never. Serious new plans to save a natural pest control. Union of Concerned Scientists, Cambridge, MA.

Moar, W. J., L. Masson, J. T. Trumble and R. Brousseau, 1990. Toxicity to Spodoptera exigua and Trichoplusia ni of individual $\mathrm{Pl}$ protoxins and sporulated cultures of Bacillus thuringiensis subsp. kurstaki HD-1 and NRD12. Appl. Environ. Microbiol. 56: 2480-2483.

Moar, W. J., M. Pusztai-Carey and T. P. Mack. 1995. Toxicity of purified proteins and the HD-1 strain from Bacillus thuringiensis against lesser cornstalk borer (Lepidoptera: Pyralidae). J. Econ. Entomol. 88: 606609.

Morrison, R. K., and R. L. Ridgway. 1976. Improvements in techniques and equipment for production of a common green lacewing, Chrysopa carnea. USDA,-ARS-S143.

Morrison, R. K., V. S. House, and R. L. Hidgway. 1975. Improved rearing unit for larvae of a common green lacewing. J. Econ. Entomol. 68: 821-822.

New, T. R. 1975. The biology of Chrysopidae and Hemerobiidae (Neuroptera), with reference to their usage as biocontrol agents: a review. Trans. R. Entomol. Soc. Lond. 127: 115-140.

Perlak, F. J., R. W. Deaton, T. A. Armstrong, R. L. Fuchs, S. R. Sims, J.T. Greenplate, and D. A. Fischhoff. 1990. Insect resistant cotton plants. BioTechnoloy 8: 939943.

Pilcher, C. D., J. J. Obrycki, M. E. Rice, and L. C. Lewis. 1997. Preimaginal development, survival, and field abundance of insect predators on transgenic Bacillus thuringiensis corn. Environ. Entomol. 26: 446-454.

Pusztai-Carey, M. P., P. Carey, T. Lessard, and M. Yaguchi. Oct. 1994. US patent No. 5356788 .

Ridgway, R. L., R. K. Morrison, and M. Badgley. 1970. Mass rearing of green lacewing. J. Econ. Entomol. 63: 834-836.

Salama, H. S., F. N. Zaki, and A. F. Sharaby, 1982. Effect of Bacillus thuringiensis Berl. on parasites and predators of the cotton leafworm Spodoptera littoralis (Boisd.). Z. Angew. Entomol. 94: 498-504. 
SAS Institute. 1988. SAS user's guide: statistics, version 6 . SAS Institute, Cary, NC.

Sims, S. R. 1995. Bacillus thuringiensis var, kurstaki (CryIA (c)) protein expressed in transgenic cotton: effects on beneficial and other non-target insects. Southwest. Entomol. 20: 493-500.

Snow, A. A., and P. M. Palma. 1997. Commercialization of transgenic plants: potential ecological risks. BioScience 47: 86-96.
Vanderzant, E. S. 1969. An artificial diet for larvae and adults of Chrysopa camea, an insect predator of crop pests. J. Econ. Entomol. 62; 256-257.

Received for publication 13 November 1997; accepted 14 May 1998. 